\title{
Richness, abundance, and mass in snake assemblages from two Atlantic Rainforest sites (Ilha do Cardoso, São Paulo) with differences in environmental productivity
}

\author{
Carlos Frederico Duarte Rocha ${ }^{1,2}$, Helena Godoy Bergallo ${ }^{1}$, Carla Fabiane Vera y Conde ${ }^{I}$, \\ Emerson Brum Bittencourt ${ }^{1}$ \& Hilda de Carvalho Santos ${ }^{1}$ \\ ${ }^{1}$ Departamento de Ecologia, Instituto de Biologia Roberto Alcântara Gomes, \\ Universidade do Estado do Rio de Janeiro - UERJ, \\ Rua São Francisco Xavier, 524, Maracanã, CEP 20550-013, Rio de Janeiro, RJ, Brazil \\ ${ }^{2}$ Autor para correspondência: Carlos Frederico Duarte Rocha, e-mail: cfdrocha@uerj.br
}

ROCHA, C.F.D., BERGALLO, H.G., VERA y CONDE, C.F., BITTENCOURT, E.B. \& SANTOS, H.C. 2008. Richness, abundance, and mass in snake assemblages from two Atlantic Rainforest sites (Ilha do Cardoso, São Paulo) with differences in environmental productivity. Biota Neotrop. 8(3): http://www.biotaneotropica. org.br/v8n3/en/abstract?article+bn01408032008.

\begin{abstract}
We analyzed richness, composition and mass of snakes in two sites in the Atlantic forest of Ilha do Cardoso (25 03' S and 47 53' W), an island (22,500 ha), Cananéia municipality, São Paulo State, Brazil. A monthly index of arthropod availability (in $\mathrm{mm}^{3}$ ) was estimated in each site through capture rates in pit-fall traps. Fallen fruits were collected along trails in the study sites (mass of fruit gave an index of fruit availability) and small mammals were sampled in grids with 120 traps which covered the lowland (5.2 ha) and in the slope forests (3.6 ha). The abundance and mass of small mammals were standardized for the size of each sampled area (in g.ha ${ }^{-1}$ ). To sample snakes we established 20 pit-fall traps in each area and performed monthly transects in four consecutive days (totaling $1000 \mathrm{~m}$ long) along trails in the study sites. Snakes found were measured, weighted marked and released. Abundance and total mass of snakes were standardized by the size of each area. The areas differed consistently in in the productivity of arthropods, fruits and small mammals, and also in richness, composition and total mass of snakes. We found 36 individuals (total mass $=9884 \mathrm{~g}$ ) of 12 snake species belonging to three Families (Colubridae, Elapidae and Viperidae) in the lowland forest, whereas in the slope forest we sampled only 9 individuals of 2 species (total mass $=1820 \mathrm{~g}$ ). Our results suggest that the area of lowland forest, showing higher productivity of arthropods, fruits and small mammals, maintains a snake community with a higher richness, diversity and biomass than its slope forest counterpart.

Keywords: Atlantic Rainforest snake assemblage, environmental productivity, snake diversity, and richness, snake seasonal activity, snake biomass.
\end{abstract}

ROCHA, C.F.D., BERGAllO, H.G., VERA y CONDE, C.F., BITTENCOURT, E.B. \& SANTOS, H.C. 2008. Riqueza, abundância e biomassa em duas comunidades de serpentes na Floresta Atlantica em sítios com diferenças na produtividade. Biota Neotrop. 8(3): http://www.biotaneotropica.org.br/v8n3/pt/ abstract?article+bn01408032008.

Resumo: Nós analisamos a riqueza, a composição e a massa de serpentes em dois ambientes na Mata Atlântica da Ilha do Cardoso (25 03' S e 47 53' W), uma ilha (22.500 ha), localizada no município de Cananéia, Estado de São Paulo, Brasil. Estimamos um índice de disponibilidade de artrópodos (em $\mathrm{mm}^{3}$ ) em cada ambiente através da taxa de captura em armadilhas de queda estabelecidas no chão da floresta. Coletamos frutos caídos ao longo de trilhas nos ambientes estudados (a massa de frutos forneceu um índice da disponibilidade de frutos) e pequenos mamíferos foram amostrados em grades com 120 armadilhas as quais cobriram um ambiente na mata de planície (5,2 ha) e um na floresta de encosta (3,6 ha). A abundância e massa de pequenos mamíferos foi padronizada para o tamanho de cada área amostrada $\left(\mathrm{em} \mathrm{g} \cdot \mathrm{ha}^{-1}\right)$. Para amostrar as serpentes estabelecemos 20 armadilhas de queda em cada ambiente e mensalmente realizamos transectos durante quatro dias consecutivos (totalizando $1000 \mathrm{~m}$ de extensão em cada área) ao longo de trilhas nos ambientes estudados. As serpentes foram medidas, pesadas, marcadas e soltas. A abundância e massa total de serpentes foram padronizadas para o tamanho de cada área amostrada. As áreas diferiram consistentemente na produtividade de artrópodos, de frutos e de pequenos mamíferos, e também na riqueza, composição e massa total de serpentes. Encontramos um total de 36 indivíduos (massa total $=9884 \mathrm{~g}$ ) de 12 espécies de serpentes pertencentes a três famílias (Colubridae, Elapidae and Viperidae) na mata de planície, enquanto na mata de encostaamostramos apenas 9 indivíduos de 2 espécies (massa total = $1820 \mathrm{~g}$ ). Nossos resultados sugerem que a mata de planície, que teve maior produtividade de of artrópodos, de frutos e de pequenos mamíferos, mantém uma comunidade de serpentes com maior riqueza, diversidade e biomassa do que a mata de encosta.

Palavras-chave: comunidades de serpentes de Mata Atlântica, produtividade ambiental, diversidade e riqueza de serpentes, atividade sazonal de serpentes, biomassa de serpentes. 


\section{Introduction}

Environmental productivity is an important determinant of species richness, diversity and biomass in biological communities (e.g. August 1983, Rozensweig 1971, 1996). For some environments such as tropical forests (e.g. Duellman 1978, Mabberley 1983, Bobrov 1993, Bergallo 1999, Bergallo \& Magnusson 1999, Vera y Conde \& Rocha 2006) including restinga habitats (e.g. Rocha \& Bergallo 1997), for deserts (e.g. Christian 1980) or coral reefs (e.g. Connell 1978), it has been shown that an increase in environmental productivity, through availability of resources, usually results in a corresponding increase in richness, abundance, diversity and total mass of particular groups of organisms.

In most communities, snakes are important predators of vertebrates, with small mammals being important prey for a number of species (Gonzaga et al. 1997, Di Bernardo 1998, Marques 1998, Martins 1994, Rocha \& Vrcibradic 1998, Marques \& Sazima 2004, Pontes \& Rocha 2008). Mammallian density and biomass tend to be strongly dependent of the availability of arthropods and fruits (Bergallo and Magnusson, 1999).

At the rainforest of Ilha do Cardoso, an island located in the coast of São Paulo State, Southeastern Brazil, two portions of the forest can be recognized due to differences in humidity, temperature and topography: the forest occurring near sea level (altitude up to to $5 \mathrm{~m}$ - hereafter referred as lowland forest - LF) and the forest of the slopes of the hills, hereafter refferred as slope forest - SF) (Giulietti et al. 1983). These two forested areas differ in altitude and inclination, which results in considerable differences in abundance of some materials such as leaf litter (Giulietti et al. 1983) and humidity, since most of the rain tends to drain towards the lower portions of the forest (Santos et al. 1998). Also, the two areas differ strongly in vegetation density and canopy height (Barros et al. 1991; Vera y Conde 1994).

Considering the differences in these two forest environments, we would expect that the variation between these segments of forest, especially in humidity, vegetation spacing and canopy height (Barros et al. 1991, Vera y Conde 1994), would affect the amount of arthropods, fruits and small mammals, which in turn would increase the availability of food resources for many snake species. This effect would influence snakes either directly, in case of snakes that prey on mammals, or indirectly, in species that prey on lizards, frogs and small mammals for which arthropods and fruits constitute important food sources. Thus, we could expect that the differences in prey abundance should affect the assemblage of snakes each of the two forest environments (in terms of species richness, total abundance and biomass).

In this study we analyze some parameters of the environmental productivity of two Atlantic Rainforest areas (Lowland forest and Slope forest) at Ilha do Cardoso in terms of arthropods, fruits and small mammals, and evaluate the richness, heterogeneity and total mass of snakes associated to each of these two forest environments.

\section{Material and Methods}

\section{Study area}

The study was carried out in an area of Atlantic Rainforest at Ilha do Cardoso (approximately $25^{\circ} 03^{\prime} \mathrm{S}$ and $47^{\circ} 53^{\prime} \mathrm{W}$ ), a large continental island (22,500 ha), located on the Southern coast of São Paulo State, Southeastern Brazil (Figure 1). The climate in the area is wet subtropical with most of the rainfall (about $70 \%$ ) between December and April. Mean annual temperature is $23{ }^{\circ} \mathrm{C}$ with coldest period in

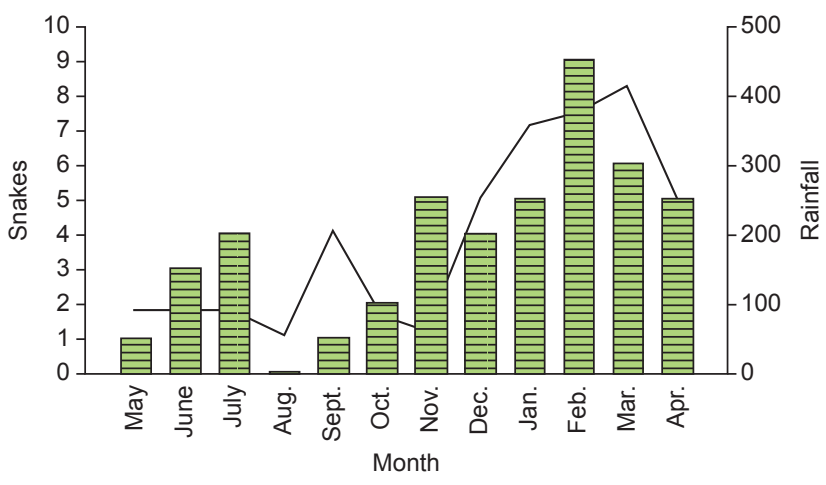

Figure 1. Relationship between monthly total number of snakes found in two areas (Lowland and slope forests) and rainfall in the Atlantic Rainforest at Ilha do Cardoso, São Paulo State, Brazil ( F = 9.404; $\left.\mathrm{R}^{2}=0.485 ; \mathrm{P}=0.012\right)$.

Figura 1. Relação entre o número total de serpentes amostradas mensalmente em duas áreas (mata de baixada e mata de encosta) e a pluviosidade na área de Mata Atlântica da Ilha do Cardoso, Estado de São Paulo, Brasil ( $F=9,404$; $\left.\mathrm{R}^{2}=0.485 ; \mathrm{P}=0,012\right)$.

July-August and the warmest period in January-February (Bergallo \& Magnusson 1999). Weather data were obtained from the Climatological Center of Ilha do Cardoso, ca. $4 \mathrm{~km}$ from the study area.

\section{Sampling methods and analysis}

\subsection{Index of arthropod availability and leaf litter}

To estimate an index of arthropod availability we made monthly samplings from May 1993 to April 1994. At each month we established, on each of the environments (LF and SF) ten pit-fall traps (10 cm diameter, $12 \mathrm{~cm}$ depth) which remained in the field for a period of 72 hours (see Santos et al. 1998 for detailed methodology). In addition, we monthly removed $1 \mathrm{~m}^{2}$ of leaf litter in each area, and sampled arthropods using Bérlese-Tullgren funnels. The arthropods found were identified to Order, counted and had their index of mass (in $\mathrm{mm}^{3}$ ) estimated by the multiplication of their three dimensions (length, width and depth). The total number and volume of arthropods found in each sampling method was summed to give the overall number and volume estimates for each month. The index of abundance of arthropods in each forest environment (LF and SF) was calculated as the cumulative number of individuals of all arthropod orders recorded along the 12-month sampling, and the index of arthropod mass as the cumulative volume (in $\mathrm{mm}^{3}$ ) of arthropods in the same period. Also, we weighted (in grams) the 12 samples of $1 \mathrm{~m}^{2}$ of leaf litter removed from the forest floor at each environment and used the mean weigth as an index of the leaf litter density at each $\mathrm{m}^{2}$ of forest floor in each area.

\subsection{Index of fruit availability}

Fallen fruits were collected monthly from May 1993 to April 1994 in 80-by 1 m-transects along 12 trails in each forest environment (LF and SF) (for details see Bergallo and Magnusson, 1999). Mass (in $\mathrm{g}$ ) of fresh fruits collected in each monthly sampling was used as an index of fruit availability for that particular month. The index of fruit productivity of each area was estimated as the cumulative mass along the 12 months standardized for the size of each area. Differences among areas in the standardized mean mass of fruits was tested using ANOVA. 


\subsection{Index of small mammal productivity}

Small mammals were sampled in a grid which covered the LF (5.2 ha) and the SF (3.6 ha). The grid was irregular and had eight trails with 15 trap stations and six trails with 20 trap stations, spaced $20 \mathrm{~m}$ apart, totaling 240 stations. Monthly, from February 1993 to January 1995, 120 traps were placed at trap stations separated by $40 \mathrm{~m}$ during two nights. Traps were moved $20 \mathrm{~m}$ on the third day, so the 240 capture stations of the grid (including both areas) could be covered in each 4-day session. Traps were baited with banana or manioc and peanut butter. Captured animals were marked with an ear perforation and weighted (to the nearest gram) using Pesola spring scales. The abundance and mass of small mammals were standardized for the size of each sampled area (in $\mathrm{g} \cdot \mathrm{ha}^{-1}$ ).

\subsection{Snake community parameters}

From May 1993 to April 1994 we performed monthly transects along the trails of the grids in the LF and in the SF searching for snakes. A total of $1000 \mathrm{~m}$ was searched monthly along transects in each forest environment. Transects were sampled in four consecutive days, in the morning (07:00-11:00 AM), afternoon (01:00-05:00 PM) and crepuscular/nocturnal period (06:00-07:00 PM). During transects each observer moved along trails in a regular slow walking pace, carefully looking for snakes on the ground, on tree trunks and branches and under fallen logs. When transects crossed a stream or passed near a pond those habitats were also carefully checked for the presence of snakes. Anytime a snake was found an attempt was made to capture it using a noose or by hand. The snakes were identified, weighted (to the nearest $1 \mathrm{~g}$ ), measured (to the nearest $1 \mathrm{~cm}$ ) in its snout-vent-length (SVL), and each was marked by an incision on its ventral scales. Marks were made to avoid counting the same individual more than once. Individuals were released at the same place they were originally found.

In addition, in each area we established 20 pit-fall traps, each consisting of a plastic reservoir of 25 liters. The pit-falls were established along a line on the forest floor, remaining with their openings at the ground level. During fieldwork, the pitfalls in the two forest environments were checked in the morning and in the afternoon for the presence of snakes. Whenever a snake was found inside a pit-fall, the same procedures reported above were made to record data from the snake sampled. We compared the two forest environments in terms of richness, abundance and mass (in g) of snakes. Snake heterogeneity in each forest environment was estimated using the Shannon index. We used an Analysis of Variance to evaluate if the mean snake mass differed between the areas. The snake abundance was related with the rainfall monthly by simple regression.

\section{Results}

The two environments studied in the forest of Ilha do Cardoso differed consistently in the indexes of productivity considered in the present study (arthropod abundance, leaf-litter mass, fruit mass and small mammal availability) (Table 1). In general, the values of arthropod abundance, arthropod mass, leaf-litter mass, index of fruits availability and small mammal mass were considerably higher in LF than in SF (Table 1). Arthropod abundance in the LF was approximately three times higher than in SF, whereas arthropod mass in the former was about eight times larger than in the last area. Similarly, leaf-litter mass in the LF was three times larger than that found in the SF. The index of fruit mass available in the LF was about twice than that found in the SF. During the study we sampled a total of 12 snake species belonging to three Families: Colubridae (Chironius bicarinatus, Chironius fuscus, Clelia plumbea, Helicops carinicaudus, Leptodeira annulata, Liophis miliaris, Rhadinaea affinis, Spilotes pullatus and Tropidodryas serra), Elapidae (Micrurus corallinus) and Viperidae (Bothrops jararaca and Bothrops jararacussu) (Table 2). Table 2 shows the number of snakes of each species recorded and the total snake mass (in g) sampled in each forest environment. The total abundance of snakes found along the study in the LF was approximately four times higher than that found in the SF. We found a total of 36 individuals belonging to 12 snake species in the LF (with a standardized abundance of 0.003 snakes $/ \mathrm{m} /$ trail) and a total of nine individuals in two snake species in the SF (with a standardized abundance of 0.00075 snakes $/ \mathrm{m} /$ trail) (Table 2). Both snake species recorded in the SF also occurred in the LF. The most abundant snakes in the area were Spilotes pullatus and Tropidodryas serra but they only occurred in the LF (Table 2). The mean snake mass did not differ between the areas $(\mathrm{LF}=274.6 \pm 223.6 \mathrm{~g}$ and $\mathrm{SF}=202.2 \pm 107.4 \mathrm{~g}$, $\mathrm{N}=45, \mathrm{~F}=0.88, \mathrm{P}=0.35$ ). However, the total snake mass found in the LF (total snake mass of $9904 \mathrm{~g}$, with a standardized sampled mass of $1904.6 \mathrm{~g} \cdot \mathrm{ha}^{-1}$ ) was approximately 5 times higher than those found in the SF (total snake mass of $1403 \mathrm{~g}$, with a standardized sampled mass of $389.7 \mathrm{~g} \cdot \mathrm{ha}^{-1}$ ). At the slopes of the SF we found only two snake species, Chironius fuscus and Bothrops jararaca (Table 2), with these species being common to both environments studied. At the LF we recorded higher overall abundance (36 individuals), species richness (12 species) and total mass (9884 g) and diversity $\left(H^{\prime}=1.919\right)$ of snakes when compared with the $S F$ (abundance $=9$ individuals; richness $=2$ species, total mass $=1820 \mathrm{~g}$ and diversity, $\left.\mathrm{H}^{\prime}=0.687\right)$ (Table 1). Most individual snakes $(\mathrm{N}=34)$ were found from November to April, whereas the number of snakes found from May to October was comparatively lower $(\mathrm{N}=11)$ (Figure 1). The

Table 1. Productivity indexes of arthropod (abundance in ind. $\mathrm{m}^{-2}$ ), leaf-litter (in $\mathrm{g}^{\mathrm{m}} \mathrm{m}^{-2}$ forest floor), small mammals (abundance in ind/ha and mass in g.ha $\mathrm{m}^{-1}$ ) and snakes in terms of total abundance, species richness, and total mass (in $\mathrm{g}$ ) found in two areas (Lowland and Slope forests) in the Atlantic Rainforest at Ilha do Cardoso, São Paulo State, Brazil.

Tabela 1. Indices de produtividade de artrópodos (abundância em ind. $\mathrm{m}^{-2}$ ), massa de folhiço (em g.m ${ }^{-2}$ de chão de floresta), pequenos mamíferos (abundância em ind.ha ${ }^{-1}$ e massa em g.ha ${ }^{-1}$ ) e de serpentes em termos de total abundância, riqueza de espécies e massa total (em g) encontrados em duas áreas (Mata de baixada e mata de encosta) na Mata Atlântica da Ilha do Cardoso, Estado de São Paulo, Brasil.

\begin{tabular}{|c|c|c|c|c|c|c|}
\hline \multirow[t]{2}{*}{ Indexes } & \multicolumn{3}{|c|}{ Lowland forest (LF) } & \multicolumn{3}{|c|}{ Slope forest (SF) } \\
\hline & Abundance & Richness & Mass & Abundance & Richness & Mass \\
\hline Arthropods & 136.7 ind. $\mathrm{m}^{-2}$ & 24 & $382 \mathrm{~mm}^{3} \cdot \mathrm{m}^{-2}$ & 47.3 ind. $\mathrm{m}^{-2}$ & 22 & $50 \mathrm{~mm}^{3} \cdot \mathrm{m}^{-2}$ \\
\hline Leaf-litter & - & - & $401.2 \pm 128.0 \mathrm{~g}$ & - & - & $133.3 \pm 97.0 \mathrm{~g}$ \\
\hline Fruits & - & - & $95.3 \pm 115.8$ & - & - & $50.9 \pm 64.8$ \\
\hline Mammals & 63.1 ind.ha $^{-1}$ & 8 & 8057 g.ha ${ }^{-1}$ & 59.4 ind. $^{-1} a^{-1}$ & 7 & 7579 g.ha ${ }^{-1}$ \\
\hline Snakes & 36 & 12 & $9904 \mathrm{~g}$ & 9 & 2 & $1824 \mathrm{~g}$ \\
\hline
\end{tabular}


Table 2. Snake species and respective number of individuals $(\mathrm{N})$ and total mass (in $\mathrm{g}$ ) found in two areas (Flat and slope forests) in the Atlantic Rainforest at Ilha do Cardoso, São Paulo State, Brazil.

Tabela 2. Espécies de serpentes e and respectivos números de indivíduos (N) e massa total (em g) encontrados em duas áreas (Mata de baixada e mata de encosta) na Mata Atlântica da Ilha do Cardoso, Estado de São Paulo, Brasil.

\begin{tabular}{|c|c|c|c|c|}
\hline \multirow[t]{2}{*}{ Snake species } & \multicolumn{2}{|c|}{ Lowland forest } & \multicolumn{2}{|c|}{ Slope forest } \\
\hline & $\mathbf{N}$ & $\begin{array}{c}\text { Mass } \\
\text { (g) }\end{array}$ & $\mathbf{N}$ & $\begin{array}{c}\text { Mass } \\
\text { (g) }\end{array}$ \\
\hline \multicolumn{5}{|l|}{ COLUBRIDAE } \\
\hline Chironius bicarinatus & 1 & 754 & - & - \\
\hline Chironius fuscus & 3 & 315 & 4 & 421 \\
\hline Clelia plumbea & 1 & 141 & - & - \\
\hline Helicops carinicaudus & 2 & 243 & - & - \\
\hline Leptodeira annulata & 1 & 82 & - & - \\
\hline Liophis miliaris & 3 & 331 & - & - \\
\hline Echinanthera affinis & 1 & 20 & - & - \\
\hline Spilotes pullatus & 10 & 4504 & - & - \\
\hline Tropidodryas serra & 6 & 1116 & - & - \\
\hline \multicolumn{5}{|l|}{ ELAPIDAE } \\
\hline Micrurus corallinus & 3 & 309 & - & - \\
\hline \multicolumn{5}{|l|}{ VIPERIDAE } \\
\hline Bothrops jararaca & 1 & 286 & 5 & 1403 \\
\hline Bothrops jararacussu & 4 & 1803 & - & - \\
\hline
\end{tabular}

relationship between monthly number of snakes found and rainfall was positive and significant $\left(\mathrm{F}=9.404 ; \mathrm{R}^{2}=0.485 ; \mathrm{P}=0.012\right)$.

\section{Discussion}

Our results indicate that the abundance of arthropods, fruits, leaf litter and small mammals in Ilha do Cardoso are consistently higher in the lowland forest (LF) when compared with slope forest (SF). Similarly, LF tended to maintain higher abundance, richness and biomass of snakes when compared to SF. Habitats with high productivity have a higher amount of available energy (Rozensweig,1996) and, as a result, can potentially mantain a large amount of species of higher throphic level such as snakes. One factor possibly contributing for the differences in snake abundances between areas is the occurrence of streams, rivulets and ponds; although these water bodies are frequent in LF, their occurrence decreases considerably in the SF. This can impose restrictions for the occurrence of some snakes which, in general, live associated to water bodies (e.g. Liophis miliaris and Helicops carinicaudus). Besides favoring the occurrence of these semi-aquatic snakes, the occurrence of those water bodies may increase the local spatial heterogeneity in the LF. Spatial heterogeneity tends to promote an increase in the diversity of resources available in a particular habitat, favoring the coexistence of a large number of species (Simpson 1964). Also, some characteristics of the structural habitat such as leaf-litter depth may also influence the local snake community, not only by increasing microhabitat space for potential preys such as frogs (Van Sluys et al. 2007) and small mammals (Kemper and Bell 1985), but may also favor the occurrence of some snake species, especially terrestrial, semi-fossorial or fossorial ones. In LF the amount of leaf-litter/ $\mathrm{m}^{2}$ of forest floor was about three times higher than that found in SF, which can provide more space and shelter protected from predators for some snakes. For semi-fossorial snake species such as Micrurus corallinus, the comparatively thinner layer of leaf litter in the SF may reduce potential microhabitats under which they could use for shelter or foraging. For example, lizard prey of the elapid Micrurus corallinus are usually leaf-litter inhabitants (Marques \& Sazima 1997). In addition in part, these differences may also result from differences in soil characteristics among areas. Soil depth and compostion in LF is also considerably different from that in SF, as this last tend to be dominated by rocky extrusions. Shallow, rocky soils would deeply limit the presence of fossorial species. In contrast, depositional soils in the lower parts would provide more suitable habitats for burrowing snakes.

Our results suggest that there is a tendency for the viperids to differ in the area of the forest they occur: Bothrops jararaca occurred more frequently at the SF whereas $B$. jararacussu was found only at the LF. It has been suggested that in some cases an incompatibility to live in sintopy may occur between two taxonomically close species, resulting in a mosaic distribution (Henderson et al. 1979). At this time we do not know if this tendency may be a result of an ecological incompatibility of these Bothrops species, although a similar segregation in occurrence has been suggested for some species of Micrurus (Henderson et al. 1979). However, alternatively, we must consider that actually these two Bothrops species are not closely related, and actually belong to distinct clades (species groups) within Bothrops (Martins et al. 2001) and this may explain the differences in macrohabitat use.

Most of the snakes in the area were found during the summer, a period of warmer temperatures and intense rainfall in the area. Rainfall explained approximately $50 \%$ of the monthly occurrence of snakes along the year. This activity trend during warmer and/ or wetter periods has also been reported for some snake species in other neotropical areas (e.g. Marques 1998, Martins \& Oliveira 1998, Rocha et al. 2000, Marques et al. 2000, Marques et al. 2001, Hartmann et al. 2002, Pizzato \& Marques 2002, Maciel et al. 2003). In tropical and subtropical areas of South America activity of snakes is usually seasonal being comparatively higher during the rainy season. This trend seems to be related to the more favorable conditions of humidity and temperature for the embryonic development (Vinegar 1977) and can be of importance for reproductive snakes especially during period of oviposition. Also, humidity and temperature are known to directly influence the metabolism of snakes, thus affecting their activity (Lillywhite 1987). The metabolic rate of snakes are usually reduced in low environmemtal temperatures which results in reduced activity (Lillywhite 1987). Another important factor favoring acvtivity in wetter periods is that humidity and temperature favors environmental productivity (Bergallo \& Magnusson 1999), which in turn tend to provide more sources of food for the snakes. This seems to be the case in Ilha do Cardoso, where most snakes seem to be active during the rainy season and snake occurrence seems to be favored in the portions of the forest with higher productivity.

\section{Acknowledgements}

We thank some of our students which in different occasions assisted us during fieldwork but particularly A. Sarmento, P. Lacerda, A. M. Marques, S. Z. Albuquerque, A. Jardim and F. Peres. We also thank the former Scientific Director of the Centro de Pesquisas Aplicadas of Ilha do Cardoso (CEPARNIC) Timothy P. Moulton who made many facilities available during the study, and the Instituto Florestal (IF), for the permit to work in the State Park. Maria R. A. Braga and R. Nogueira helped in many aspects. D. Vrcibradic kindly revised the manuscript offering helpful suggestions. This study was partially supported by Fundação de Amparo à Pesquisa do Estado de São Paulo (FAPESP) through research grant to HGB (Process 
n 92/4619-7), by Sub-Reitoria de Pós-Graduação e Pesquisa (SR-2) of The Universidade do Estado do Rio de Janeiro (UERJ) which provided logistic support and a Scientific Initiation Grant to HCS. CFDR (Processes 307653/2003-0 and 477715/06-0) and HGB (Process 309527/06-6) receive research grants from Conselho Nacional do Desenvolvimento Científico e Tecnológico (CNPq).

\section{References}

AUGUST, P.V. 1983. The role of complexity and heterogeneity in structuring tropical mammal community. Ecology 64(6):1495-1507.

BARROS, F., MELO, M.M.R.F., CHIEA, S.A.C., KIRIZAWA, M., WANDERLEY, M.G.L. \& JUNG-MENDAÇOLLI, S.L. 1991. Flora fanerogâmica da Ilha do Cardoso - caracterização geral da vegetação e listagem das espécies ocorrentes. Instituto de Botânica, São Paulo.

BERGALLO, H.G. \& MAGNUSSON, W.E. 1999. Effects of climate and food availability on four rodent species in southeastern Brazil. Journal of Mammalogy 80(2):472-486.

BITTENCOURT, E.B., Vera y Conde, C.F., ROCHA, C.F.D. \& BERGALLO, H.G. 1999 Activity patterns of small mammals in an Atlantic forest area of southeastern Brazil. Ciência e Cultura 51(2):126-132.

BOBROV, V.V. 1993. Spatial organization of a tropical lizard community in a forested area in northern Vietnam. Herpetozoa 6(1/2):21-28.

CONNELL, J.H. 1978. Diversity in Tropical Rain Forests and Coral Reefs - High diversity of Trees and Corals is Maintained Only in a NonEquilibrium State. Science 199(4335):1302-1310.

CHRISTIAN, D.P. 1980. Vegetative Cover, Water Resources and Microdistributional Patterns in a Desert Rodent Community. Journal of Animal Ecology 49(5):807-816.

DI BERNARDO, M. 1998. História Natural de uma comunidade de serpentes da borda oriental do planalto das araucárias, Rio Grande do Sul, Brasil. Tese de Doutorado, Instituto de Biociências, Universidade Estadual Paulista, Campus de Rio Claro, Rio Claro. 119p.

DUELLMAN, W.E. 1978. The biology of an equatorial herpetofauna in amazonian Ecuador. Misc. Publ. Mus. Nat. Hist. Univ. Kans. 65:1-352.

FUNARI, F.L., STRUFFALDI-DE-VUONO, Y. \& SALUM, S.T. 1987. Balanço hídrico de duas áreas de mata Atlântica: Reserva Biológica de Paranapiacaba e Parque Estadual da Ilha do Cardoso (Estado de São Paulo). In Anais do VI Congresso da Sociedade Botânica de São Paulo. (M.F.A. Pereira \& M.A.S Massei, eds.). Sociedade Botânica de São Paulo, Campinas. p. 95-101.

GIULIETTI, A.M., RIBEIRO-FILHO, E., BUENO, M.S.G. \& AVELAR, W.E.P. 1983. Em busca do conhecimento ecológico - uma introdução à Metodologia. Edgar Blucher Ltda, São Paulo. 110p.

GONZAGA, L.A.P., CASTIGLIONI, G.A.D. \& ALVES, M.A.S. 1997. Philodryas patagoniensis diet. Herp. Review 28(3):154.

HARTMANN, M.T., DEL GRANDE, M.L., GONDIM, M.J., MENDES, M.C. \& MARQUES, O.V.A. 2002. Reproduction and activity of the snail-eating snake Dipsas albifrons (Colubridae) in the Southeastern Atlantic forest of Brazil. Stud. Neot. Fauna \& Environ. 37(2):111-114.

HENDERSON, R.W., DIXON, J.R. \& SOINI, P. 1979. Resource partitioning in Amazonian snake communities. Milw. Public Mus. Contr. Biol. Geol. 22(1):1-11.

KEMPER, C. \& BELL, D.T. 1985. Small Mammals and Habitat Structure in Lowland Rain Forest of Peninsular Malaysia. J. Trop. Ecol. 1(1):5-22.

LILLYWHITE, H.B. 1987. Temperature, energetics and physiological ecology. In Snakes: Ecology and Evolutionary Biology. (Seigel, R.A., Collins, J.T. \& Novak, S.S. eds.). MacMillan Publ. Co., New York, p.422-477.

MACIEL, A.P., DI-BERNARDO, M., HARTZ, S.M. \& OLIVEIRA, R.B. 2003. Seasonal and daily activity patterns of Liophis poecilogyrus (Serpentes: Colubridae) on the north coast of Rio Grande do Sul, Brazil. Amphibia-Reptilia 24(2):189-200.

MARQUES, O.A.V. 1998. Composição faunística, História Natural e ecologia de serpentes da Mata Atlântica, na região da Estação Ecológica Juréia-
Itatins, São Paulo, SP. Tese de Doutorado, Departamento de Zoologia, Instituto de Biociências, Universidade de São Paulo, São Paulo. 135p.

MARQUES, O.A.V., ETEROVICK, P. \& ENDO, W. 2001. Seasonal activity of snakes in the Atlantic forest in Southeastern Brazil. Amphibia-Reptilia 22(1):103-111.

MARQUES, O.A.V. \& SAZIMA, I. 1997. Diet and behavior of the coral snake, Micrurus corallinus from the Atlantic Forest of Brazil. Herp. Nat. Hist. 5(1):88-93.

MARQUES, O.A.V. \& SAZIMA, I. 2004. História Natural dos Répteis da Estação Ecológica Juréia-Itatins. In Estação Ecológica da Juréia-Itatins. Ambiente Físico, Flora e Fauna. (Otavio A.V. Marques \& W. Duleba, orgs.). Editora Holos, Ribeirão Preto. 386p.

MARTINS, M. 1994. História Natural e ecologia de uma taxocenose de serpentes de Mata na região de Manaus, Amazônia Central, Brasil. Tese de Doutorado, Instituto de Biologia, Universidade Estadual de Campinas, Campinas. 98p.

MARTINS, M. \& OLIVEIRA, E. 1998. Natural History of snakes in forests of the region of Manaus, Central Amazônia, Brazil. Herpetological Nat. Hist. 6(2):78-150.

MARTINS, M., ARAÚJO, M.S., SAWAYA, R.J. \& NUNESI, R. 2001. Diversity and evolution of macrohabitat use, body size and morphology in a monophyletic group of Neotropical pitvipers (Bothrops). Journal of Zoology 254(4):529-538.

PAGLIA, A.P., DE MARCO, P., COSTA, F.M., PEREIRA, R.F., LESSA, G. 1995. Heterogeneidade estrutural e diversidade de pequenos mamíferos em um fragmento de mata secundária em Minas Gerais. Revista Brasileira de Zoologia 12(1):67-79.

PIZZATTO, L. \& MARQUES, O.A.V. 2002. Reproductive biology of the false coral snake Oxyrhopus guibei (Colubridae) from Southeastern Brazil. Amphibia-Reptilia 23(4):495-504.

PONTES, J.A.L. \& ROCHA, C.F.D. 2008. Serpentes da Serra do Mendanha, Rio de Janeiro, RJ: Ecologia e Conservação. 1 ed. Technical Books, Rio de Janeiro. 147p.

ROCHA, C.F.D. \& VRCIBRADIC, D. 1998. Reptiles as predators and as preys in a restinga habitat of Southeastern Brazil. Ciência e Cultura 50(5):364-368.

ROCHA, C.F.D., LACERDA, P., SARMENTO, A. \& MARQUES, A.M. 2000. Introduction to the snake fauna of na área of Atlantic Rainforest in Southeastern Brazil (Casimiro de Abreu, RJ). In Anais do V Simpósio Brasileiro de Ecossistemas. ACIESP, Vitória, E.S.

ROSENZWEIG, M.L. 1971. Paradox of enrichment: destabilization of exploitation ecosystems in ecological time. Science 171(3969):385-387.

ROSENZWEIG, M.L. 1996 Species diversity in space and time. Cambridge University Press, Cambridge. 436p.

SIMPSON, G.G. 1964. Species diversity of North America: Recent mammals. Systematic Zoology 13(1):57-73.

SANTOS, H.C., ROCHA, C.F.D., BERGALLO, H.G. 1998. A produtividade, diversidade e abundância da mesofauna do litter em dois segmentos de Mata Atlântica (Mata de Planície e Mata de Encosta) na Ilha do Cardoso, Cananéia, São Paulo. Anais do Seminário Regional de Ecologia (VIII):823-836

VAN SLUYS, M., VRCIBRADIC, D., ALVES, M.A.S., BERGALLO, H.G.\& ROCHA, C.F.D. 2007. Ecological parameters of the leaf-litter frog community of an Atlantic Rainforest area at Ilha Grande, Rio de Janeiro State, Brazil. Austral Ecology 32(3):254-260.

VERA y CONDE, C.F. 1995. Uso do microhabitat por Nectomys squamipes (Rodentia) no Parque Estadual da Ilha do Cardoso, Cananéia, SP. Dissertação de Bacharelado, Setor de Ecologia, Departamento de Biologia Animal e Vegetal, Universidade do Estado do Rio de Janeiro, Rio de Janeiro. 34p.

VERA y CONDE, C.F. \& ROCHA, C.F.D. 2006. Habitat disturbance and small mammal richness and diversity in an Atlantic Rainforest area in Southeastern Brazil. Brazilian Journal of Biology 66(4):983-990. 
Rocha, C.F.D. et al.

VINEGAR, A. 1977. Evolutionary implicationsof temperature induced anomalies of development on snake embryos. Herpetologica 30(1):72-74.

VITT, L.J. \& VANGILDER, L.D. 1983. Ecology of a snake community in northeastern Brazil. Amphibia-Reptilia 4(2-4):273-296.
ZAR, J.H. 1999. Biostatistical Analysis. 4 ed. Prentice Hall, Inc., Upper Saddle River. 663p.

Data Received 08/12/07 Revised 03/08/08 Accepted 12/08/08 